\title{
Correlation of the Use Online Test Methods in Improving Student Problem Solving Skills in Virtual Learning During the Covid-19 Pandemic in Indonesia
}

\author{
Riyadi* \\ History Education Department \\ Faculty of Social Sciences and Law, \\ Universitas Negeri Surabaya, Indonesia \\ riyadi@unesa.ac.id
}

\author{
Rojil Nugroho Bayu Aji \\ History Education Department \\ Faculty of Social Sciences and Law, \\ Universitas Negeri Surabaya, Indonesia \\ rojilaji@unesa.ac.id
}

\author{
Eko Satriya Hermawan \\ History Education Department \\ Faculty of Social Sciences and Law, \\ Universitas Negeri Surabaya, Indonesia \\ ekohermawan@unesa.ac.id
}

\begin{abstract}
During the pandemic, which shows 19 which hit most of the countries of the world from the beginning of $\mathbf{2 0 2 0}$ making a significant transformation in various fields, including in the field of education which mostly uses education at home. About before this period comes, the world community has become a family even very family with a digital world using the internet network. In the field of learning many applications are used in conversations in Indonesia, among others: zoom, various LMS, google classes, google meet, social media, personal websites, even chat applications, including the most popular with WhatsApp application. The use of online learning applications also impacts the use of online tests as well. This study will look at the main problems associated with the use of online tests on the ability to solve students' problems in the future COVID 19 pandemic in Indonesia. This research uses quantitative methods with simple linear regression statistical operation techniques. The respondents used were two classes of students who took the Pancasila education course at Surabaya State University. The results obtained mean that there is no significant difference between the forms of tests used in both paper tests and online tests on the ability to solve problems. Online tests only facilitate test activities, but not for strategies to strengthen student skills to improve problem solving skills.
\end{abstract}

Keywords: online learning, online tests, problem solving skills

\section{INTRODUCTION}

Education is one of the pillars of national development, the development and innovation of education continues to be made to adjust to the demands of the times. Basic education in Indonesia is currently faced with the development of the Indonesian population in terms of population growth of productive age. At present the population of Indonesia of productive age (15-64 years) is more than the non-productive age (children aged $0-14$ years and parents aged 65 years and over) [1]. The population of this productive age will reach its peak in 2020-2035 when the figure reaches $70 \%$. Therefore the big challenge faced is how to strive so that the abundant productive age human resources can be transformed into human resources that have competence and skills through education so as not to become a burden (Permendikbud number 59 of 2014)[2].

According to the Minister of Education and Culture Regulation Number 20 Year 2016 concerning Competency Standards Graduates say that education is a tool to develop capabilities and shape the character of the nation's civilization as a manifestation of the ideals of the State by developing the potential of students who believe in God Almighty, have noble, healthy, knowledgeable, capable, creative, independent, and become democratic and responsible citizens.[3]

In 2019, the Human Development Reports released data calculated through the Education Index which said that Indonesia's educational position in ASEAN ranked seventh out of 9 countries with a score of 0.694 . This figure is calculated based on the Mean Years of Schooling and Expected Years of Schooling. By looking at these data we can find out that the condition of the education of the State of Indonesia is still very low[3]. Whereas a country looks at its level of progress by looking at the quality of its HR. For that, there are still many things that must be improved in order to improve the quality of human resources through education.[4]

In Law Number 20 Year 2003 it is explained that the National Education Standards include minimum criteria regarding the existing system in all jurisdictions of the Unitary Republic of Indonesia. The criteria for competency of Indonesian education graduates based on the 2013 Curriculum include three dimensions, namely attitude (affective)[5], knowledge (cognitive) and skills (psychomotor). Each dimension has a student achievement formula or criteria as a benchmark that students must master during learning. that, educators must design a more interesting and interactive learning process by utilizing media and learning resources.[4]

Entering the 21st century the demand for education is getting heavier, where knowledge and information are widely spread and technology is growing rapidly (Daryanto\&Syaiful Karim, 2017: 2). One of the important things integrated in the National Curriculum (Hendra Kurniawan, 2018: 15) is a 21st century learning 
namely 4C (Communication, Collaboration, Critical Thinking and Problem Solving, and Creativity and Innovation). Hopefully that students are truly ready to plunge into the competitive global society. Mastery of these skills is considered important in order competing in a fast and dynamic developing world.[6]

Learning is not just a "transfer of knowledge", but the most important thing is how lecturers instil values to students, and equip them with various abilities that are useful for solving problems encountered. Lecturers should design learning that is able to awaken the potential of students in using their thinking skills to solve problems. One such learning model is "Problem Based Learning (PBL)" or what we often call problem-based learning (PBM). Lecturers present problems in class, then students solve these problems with all their knowledge and skills from various sources that can be obtained[7].

With these demands, the implementation in the midst of this pandemic must also be prepared as closely as possible to the real class. In the case of exams, it must also use the online exam mechanism. In this study used questions that were designed with a quiz maker and shared with a link drive. This research will see how much influence the use of online tests on the ability to solve student problems during the COVID 19 pandemic in Indonesia. This research uses quantitative methods with simple linear regression statistical operation techniques [8]. The respondents used were two classes of students taking Pancasila education courses at Surabaya State University. The results obtained are that there is no significant difference between the forms of tests used both paper tests and online tests on the ability to solve problems. Online tests only facilitate test activities, but not for strategies to strengthen student skills in enhancing problem solving skills.[9]

\section{METHOD}

Problem-Based Learning, originally developed at a medical campus in Ontario, Canada in the 1960s (Barrows, 1996). This approach was developed based on the fact that many young doctors who had just graduated from the medical campus had very broad knowledge, but lacked sufficient skills to utilize this knowledge in daily practice. Further development, PBL is more widely applied in various subjects on campus and in higher education.

This research is a type of quantitative research using pre-experimental research methods with one shoot case study design, using this design research model the experimental results are dependent variables that are not influenced by independent variables. Thus, in the study there were no control variables and the sample were not chosen randomly. According to Sugiyono (2016) an experimental research method is defined as a research method used to look for the effect of certain treatments on other things under controlled conditions. The experimental research method in this study was used as a method to determine the effect of Student Thinking Activity Sheets (LKPD) based on critical thinking on students' problemsolving abilities.

The experimental research design used in the form of one shoot case study design is a research design that provides treatment to a group and the results are then observed[10]. The following is a description of Pretestposttest control group design based on the above design:

\section{O}

\section{Design Research Design One Shoot Case Study Design} Information:

$\mathrm{X}=$ Treatment in the form of an online test.

$\mathrm{O}=$ student problem solving ability.

\section{RESULTS AND DISCUSSION}

Problem Based learning (PBL) is a teaching method with a focus on solving real problems. The process by which students carry out group work, feedback, discussion, which can serve as a stepping stone for investigations, investigations and final reports. Thus, students are encouraged to be more actively involved in subject matter and develop critical thinking skills.

PBL is learning that uses real problems (authentic) that are not structured (ill-structured) and are open as a context for students to develop skills to solve problems and think critically as well as to build new knowledge. PBL is in line with the philosophy of constructivism which emphasizes students to actively build their own knowledge through their interactions with real problems. The main purpose of PBL is not to transfer knowledge to students, but rather to develop critical thinking skills and problemsolving abilities and at the same time develop the ability of students to actively build their own knowledge. PBL is also intended to develop students' learning independence and social skills. Learning independence and social skills can be formed when students collaborate to identify information, strategies, and learning resources that are relevant for solving problems[11].

The theory which is used as the basis of the Problem Based Learning model is modern cognitive psychology theory, which suggests that learning is a process in which students actively construct their knowledge through interactions with the environment and learning designed by learning facilitators, in this case lecturers. According to Gisjelairs, 1996 (Suci, 2008) the theory developed in PBL contains two principles namely learning is a construction process not a process of receiving (receptive process) and learning is influenced by social interaction factors and the contextual nature of the lesson. This theory directs that in the process of teaching and learning students process the construction of knowledge from the materials obtained.

In addition to the knowledge construction process, social interactions between students and students also occur between students and lecturers. Furthermore, the basis for the problem-based learning theory is collaboratives, a view that explains that students will compile knowledge by building reasoning from all the knowledge they have acquired and from everything obtained as a result of interacting with fellow individuals. This view also implies that the learning process moves from the transfer of facilitator information to the social and individual construction of knowledge processes. According to the 
constructivism approach, humans can only understand through everything they construct themselves.

Problem based learning has the idea that learning can be achieved if educational activities are centered on tasks or problems that are authentic, relevant, and presented in a context. The method is intended so that students have experience as they will later face in real life in the community. The experience is very important because effective learning starts with concrete experiences. Questions, experiences, formulations, and conceptualization of the problems they created themselves are the basis for learning.

There have been many definitions of PBL delivered by experts, which in essence can be concluded that PBL is a learning model by using problems as triggers, so that students will then solve these problems. Many research results show positive results from the application of PBL. As research by Gijselaers (1996) shows that the application of PBL makes students able to identify information that is known and needed and strategies needed to solve problems. So, the application of PBL can improve students' ability to solve problems.[12]

Based on the theory developed by Barrow, explains the characteristics of PBL are as follows:

1. Learning is student-centered, meaning that the learning process in PBL places more emphasis on students as learning people. Therefore PBL is also supported by constructivism theory where students are encouraged to be able to develop their own knowledge.

2. Authentic problems form the organizing focus for learning, the problems presented to students are authentic problems so students can easily understand the problem and can apply it in real life in the community.

3. New information is acquired through self-directed learning, in the process of problem solving it is possible that students have not understood all the prerequisite knowledge, so students try to search for themselves through various sources.

4. Learning occurs in small groups, so that scientific interaction and exchange of ideas occurs in an effort to build collaborative knowledge, PBL is conducted in small groups. The group created requires a division of tasks and setting clear goals.

5. Teachers act as facilitators, although in PBL the lecturer only acts as a facilitator but the lecturer must always monitor the progress of student activities and encourage students to achieve the desired targets.

The problem-based learning model refers to other principles of learning such as project-based learning, experience-based instruction, authentic learning and meaningful learning (anchored instruction). The model is suitable for developing higher-order thinking skills because with this model students will be helped to process information that has already become in their minds, and arrange their own knowledge about the social world and its surroundings. [9]

Based on calculations show that the results of a simple linear regression test using SPSS version 24 is used to answer the problem formulation of:

$\mathrm{H} 0$ : There is no effect of online tests on problem solving skills.
Ha: there is an influence of online tests on problem solving skills.

Formulating a simple linear regression equation, the formula for a simple linear regression equation is generally $\mathrm{Y}=\mathrm{a}+\mathrm{bX}$. Then the simple linear regression equation is obtained as follows:

$\mathrm{Y}=$ Learning Outcomes Variable

$\mathrm{a}=$ constant value from the Unstandardized Coefficients table of 38,028

$\mathrm{b}=$ regression coefficient value of 0.498

$\mathrm{Y}=38,028+0,498 \mathrm{X}$

From the simple linear regression equation above it is known that the value of the regression coefficient is positive (+), thus showing that CT CT (X) has a positive effect on the problem-solving ability of students (Y).

Hypothesis test with a significance level of 0.05 with Table. Based on the results of table 4.5 the significance value of 0.027 is known, so it has a smaller value than the significance level of 0.05 . Whereas count has a value of 2,324 greater than the table value of 2,045. Thus, the comparison shows the online test $(\mathrm{X})$ influences the ability of problem solving (Y).[10]

Based on the test curve shows that the value of counting is greater than the value of $\mathrm{T}$ table which is equal to 2.324> 2.045 and more than the critical value of significance level of 0.05 which is 1.96 . So, by looking at the hypothesis test curve image it can be concluded that $\mathrm{H} 0$ is rejected while Ha can be accepted. Besides that, based on the Model Summary section, there is a value that indicates the influence of CT LKPD on the ability of problem solving by looking at the value of R Square in the SPSS output table. It is known that the value of R Square is 0.157 which means that the influence of the CT LKPD on the problem solving ability of students is $15.7 \%$ [10]

Based on the description of the results of research data analysis, the following discussion can be presented to answer the research problem formulation and test the research hypothesis.

\section{CONCLUSIONS AND SUGGESTIONS}

\section{A. Conclusion}

Based on the calculation of table 4.9 shows the average value of one class in the assessment of individual problem-solving ability tests obtained a value of 57.45. That is, in this test students have not yet reached the Learning Completion Criteria for history subjects that have been determined by the school is 80 . Thus, each student has not yet reached mastery learning. However, there is one student whose learning completeness criteria has been reached namely with the acquisition of a value of 82 . In addition, there are five students who have almost reached the Learning Completion Criteria with the acquisition of a value of 70

\section{B. Suggestions}

Online evaluation in online learning has no effect on students' problem-solving skills, so the form of evaluation prepared by lecturers should be at a high cognitive level. Lecturers can arrange questions of analysis, synthesis, and project. Lecturers need not fear that 
independent evaluations in each student's home will make the credibility and authenticity of the answers. That will not happen because the concept of higher education learning uses the concept of andragogy.

\section{REFERENCES}

[1] J. Budi, Pendidikan Kewarganegaraan Untuk Perguruan Tinggi. Jakarta: PT. Rajagrafindo Persada, 2014.

[2] Sapriya, Konsep Dasar Pendidikan Kewarganegaraan. Bandung: Laboratorium PKn UPI, 2017.

[3] F. Ismail, "Manajemen Berbasis Sekolah: Solusi Peningkatan Kualitas Pendidikan," J. Pendidik. Islam Iqra', 2018.

[4] B. R. Joyce, M. Weil, and E. Calhoun, Models of Teaching, 5th Edition. 1996.

[5] C. K. S. Donald Ary, Lucy Cheser Jacobs, Asghar Razavieh, Introduction to Research in Education
Eighth Edition. 2009.

[6] Michael, "Dasar-dasar Utama Praktek Belajar Kewarganegaraan,” Jakarta, 2012.

[7] A. Yahya and R. Machfiroh, Civic Education di Perguruan Tinggi Indonesia. Bandung: Alfabeta, 2014.

[8] Kokom Komalasari, Pembelajaran Kontekstual, Konsep dan Aplikasi. 2013.

[9] A. Supriati and M. Umar, "Optimization of the Civic Education as the Effort to Strengthen National Character in Multicultural Community," vol. 251, no. Acec, pp. 193-196, 2018.

[11]Velasco, and A. I. Molina, "Analyzing the influence of a visualization system on students' emotions: An empirical case study," Comput. Educ., vol. 149, 2020.

[12] D. Koesoema A, Pendidikan Karakter: Strategi Mendidik Anak di Zaman Global. Jakarta: Grasindo, 2007. 